\title{
CROP QUALITY ASPECTS OF POTATO VARIETIES AND BREEDING CLONES IN ORGANIC FARMING SYSTEMS
}

\author{
Lidija VOJEVODA, Institute of Agricultural Resources Resources and Economics, 2 Liela Street, Jelgava, LV-3001, Latvia \\ lidija.vojevoda@arei.lv (corresponding author) \\ Ilze SKRABULE, Institute of Agricultural Resources Resources and Economics, 2 Liela Street, Jelgava, LV-3001, Latvia, \\ ilze.skrabule@arei.lv
}

One of the indicators of quality is the starch content of the tubers. In order to evaluate the starch content for each genotype, the Institute of Agricultural Resources and Economics had set up a field trial in organic crop production system with 10 potato varieties and 10 breeding clones. A field trial was carried out in 2018-2020. The aim of the study was to evaluate and select potato varieties and clones with high starch content in the organic farming system.

The results proved impact of meteorological conditions on the starch content in the potato tubers. Starch content of varieties and clones varied from $12.68 \%$ to $20.63 \%$ on average in 3 years, significant impact of genotypes and years were observed $(\mathrm{p}<0.05)$. The highest starch content was found in 2019 for the variety 'Kuras' (21.32\%) and for clones 19922.29 (21.0\%) and 2008-6.5 (21.11\%), also the following year these clones had a high starch content of (20.9\%) and (21.17\%), respectively. The high starch content in 2020 was also for the early varieties 'Monta' and 'Rigonda', 'Prelma' (21.17\%). In 2018, many varieties and clones had a significantly lower starch content compared to 2019 and $2020(\mathrm{p}<0.05)$.

Keywords: potato, starch content, starch yield, meteorological conditions.

\section{INTRODUCTION}

In breeding program of new potato varieties, not only the yield potential of the genotype, disease resistance, but also the quality aspects of the tubers are always taken into account. One of the indicators of quality is the starch content in the tubers. Starch is a polysaccharide, consisting of two polymers: amylose and amylopectin (Li et al.,2006). In potatoes, starch is formed by photosynthesis, first in the green leaves and then accumulates in the tubers (Soest, 1996). Starch from potato tubers is one of the most important ingredients as it is used as a raw material in many industrial processes. The main nutrient of potatoes are carbohydrates, particularly starch and starch is the second main ingredient after water in tubers (Kuur et al., 2002). Potatoes have a high energetic value $(340 \mathrm{~kJ})$ due to their starch content (Jimenez et al., 2009). Potato starch ranks third in world production after maize and wheat starches. Its unique properties differ from those of cereal and pulse starches and are directly related to its molecular structure and organization (Stijn et al.,2020). If the starch content is above 20\%, the genotype will be useful for processing into starch. Table potato varieties contain from 14 to $19 \%$ starch in tubers. Potato genotypes with starch content less than $14 \%$ are useful as dietary products (Симаков, 2008). Starch content depends on several factors: genotype, maturity, growing conditions (Kita, 2002). A multi-year field trial with varieties revealed that tuber yield and tuber size differed significantly between farming systems. Studies in Latvia proved impact of growing conditions on starch content changes for several varieties (Skrabule et al., 2018). However, the effect of the farming system on the dry matter and starch content in tubers is inconsistent: J. Hajšlova et al. (2005) and J.F. Herencia et al. (2011) reported significantly lower dry matter and starch contents in tubers grown conventionally, whereas other studies did not find significant differences between farming systems.

In Latvia, a potato starch processing company ('Aloja Sterkelsen') expands starch production each year. In 2020, a total of 1853 tons of potato starch was produced, including 100 tons of organic starch. It is planned to increase the production of organic starch in the future, as it is in demanded both in Latvia and abroad.

The aim of the study was to evaluate and select potato varieties and clones with high starch content in the organic farming system.

\section{MATERIALS AND METHODS}

The research was arranged at AREI Stende Research Center in 2018 -2020 in the field of the organic farming system in 4 replicates with 10 potato varieties: 'Monta', 'Rigonda', 'Lenora', 'Prelma', 'Brasla', 'Jogla', 'Imanta',

Copyright (C) 2021 The Authors. Published by Vytautas Magnus University. This is an open-access article distributed under the terms of the Creative Commons Attribution License (CC BY 4.0), which permits unrestricted use, distribution, and reproduction in any medium, provided the original author and source are credited. 
'Magdalena', 'Kuras' and 10 breeding clones: S 07169-35; 2008-6.5; S 07131-15; S 10063-128; S 10063-48; 19922.29; 2001-33.17; S 09035-22; 19694.5; S 07156-22. The potatoes were planted in the third decade of May, by hand and within a distance of $0.3 \mathrm{~m}$ between the tubers and $0.70 \mathrm{~m}$ between rows in the organic field. Soil in the field was: podzolized glazed loamy sand, sandy loam with soil acidity $\mathrm{pH}_{\mathrm{KCl}}-5.6-6.3$, organic matter content $2.5 \%, \mathrm{P}_{2} \mathrm{O}_{5}-250$ $\mathrm{mg} \mathrm{kg}^{-1}$ and $\mathrm{K}_{2} \mathrm{O}-110-140 \mathrm{mg} \mathrm{kg}^{-1}$. After planting the potato plots were loosed 4 times and harrowed once. As treatment against the Colorado potato beetle (Leptinotarsa decemlineata) was used permitted at the organic system insecticide Neemazal, at a dose of $1 \mathrm{~L}$ per hectare twice a season.

The starch content was determined as soon as possible after harvest for all genotype samples at same time. The starch content was determined using underwater weight. The genotype samples were selected from mechanically uninjured and disease-free tubers. The selected sample was washed and dried. The method makes it possible to determine the amounts of starch and high molecular weight starch degradation products in a sample in order to verify compliance with the declared energy value (provisions of Annex VII) and Council Directive 96/25 / EC (1).

Analyse of variance was applied for data interpretation. The correlation coefficient was calculated using the MS Excel function CORREL.

Climatic conditions. In 2018 climatic conditions were unfavourable for the potato vegetation. The drought and heat did not promote germination of seed tubers. According to the meteorological data, the soil temperature and in June exceeded $+25-+27{ }^{\circ} \mathrm{C}$ in the end of May, which was not suitable for development of sprouts (Fig. 1). In 2019 and 2020 the precipitation and air temperature were optimal in season for potato growing and development. In 2019, spring was comparativelly warm, the air temperature in April and May was above long term data, but the amount of precipitation was insufficient for vegetation, but in June and July it often rained and the amount of precipitation in July was above norm. Air temperature in this year was close to long term data, on average $+15.7^{\circ} \mathrm{C}$. In moderately warm and rainy July, potatoes develop quite well. August was warm and relatively dry, the rainfall was below long term data, but the moisture content in soil was sufficient for the tuber developing. Potato varieties and clones had favourable weather for starch acumulation. To characterize the moisture supply of the annual vegetation season, a hydrotemic coefficient was calculated. Hydrothermal coefficient has been calculated by applying formula of G. Selyaninov: HTC $=\Sigma \mathrm{x} / \Sigma \mathrm{t}$ x 10; where $\Sigma \mathrm{x}$ and $\Sigma \mathrm{t}-$ accordingly sum of precipitations and temperatures in the period, when the temperature has not been lower than $10^{\circ} \mathrm{C}$. $\mathrm{HTC}$ was 0.25 in 2018, 0.35 in 2019 and 0.44 in 2020, which indicates insufficient humidity.

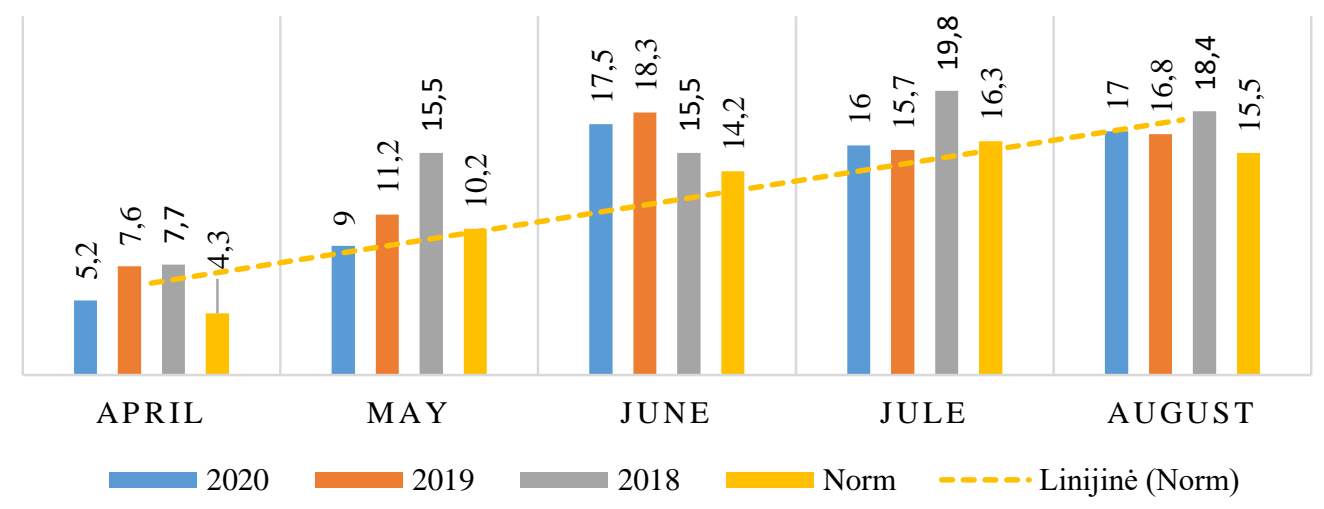

Figure1. Air temperature during trial years, ${ }^{\circ} \mathrm{C}, 2018 .-2020$.

In 2020, the amount of precipitation was below the monthly norm in Stende in April and May. In May, rain was mostly in the 3rd decade of the month. Humidity in soil and air temperature were optimal during planting. Potatoes sprouting was observed evenly after 3 weeks. An average air temperature was about $+17.5^{\circ} \mathrm{C}\left(3.3^{\circ} \mathrm{C}\right.$ above norm) in June, temperature was for $0.3^{\circ} \mathrm{C}$ lower than norm in July, and for $1.5^{\circ} \mathrm{C}$ higher than norm in August.

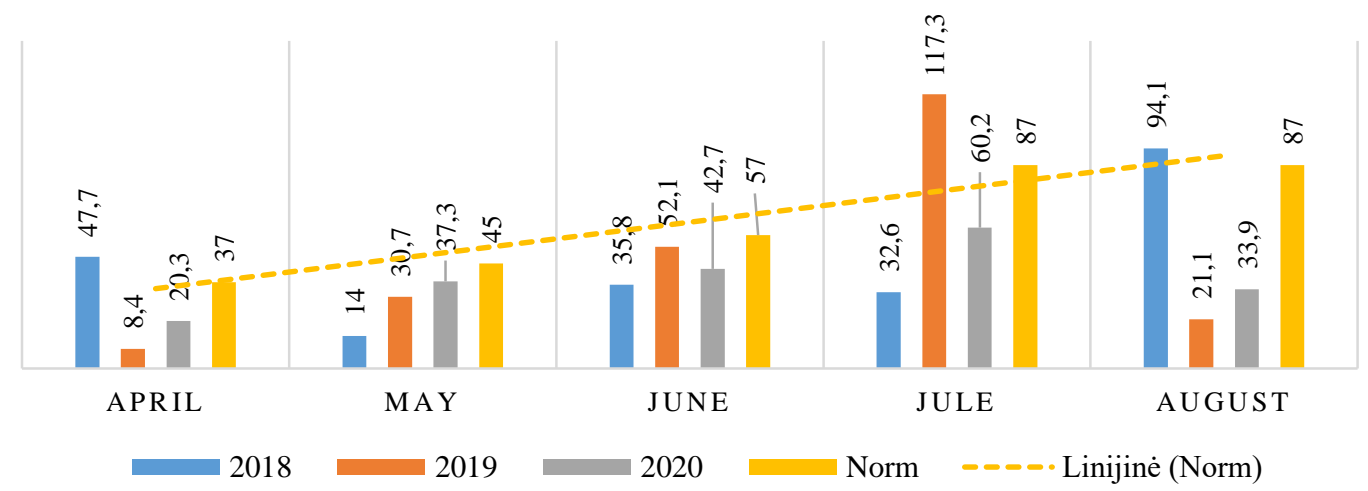

Figure 2. Total precipitation during trial years, mm, 2018-2020. 
Precipitation was $74.9 \%, 69.2 \%$ and $39 \%$ of the norm, respectively (Fig. 2). The weather conditions were suitable for potato development. Moisture in the soil was sufficient and the air temperature was acceptable.

\section{RESULTS AND DISCUSSION}

The results proved impact of meteorological conditions on the starch content in the potato tubers. Starch content of varieties and clones varied from $13.77 \%$ to $20.56 \%$ on average in 3 years, significant impacts of genotypes and years were observed $(\mathrm{p}<0.05)$.

Table 1. Starch content of potato varieties and clones in tubers, $\%, 2018-2020$

\begin{tabular}{|l|c|c|c|c|}
\hline Varieties/ breeding materials & 2020 & 2019 & 2018 & Average, starch content, $\%$ \\
\hline Monta & 21.17 & 17.09 & 15.02 & 17.76 \\
\hline Rigonda & 21.17 & 16.97 & 13.67 & 17.27 \\
\hline S 07169-35 & 14.1 & 12.54 & 14.67 & 14.77 \\
\hline 2001-33.17 & 16.19 & 15.06 & 11.78 & 16.35 \\
\hline Lenora & 19.6 & 17.55 & 11.89 & 15.99 \\
\hline Prelma & 21.17 & 12.16 & 14.63 & 17.13 \\
\hline S 07131-15 & 21.17 & 16.72 & 13.5 & 14.20 \\
\hline S 10063-128 & 14.1 & 15.15 & 13.35 & 15.17 \\
\hline S 10063-48 & 14.1 & 13.96 & 17.45 & 14.30 \\
\hline S 09035-22 & 14.1 & 13.67 & 15.13 & 15.72 \\
\hline S6694.5 $07156-22$ & 18.89 & 18.87 & 12.39 & 20.09 \\
\hline Brasla & 16.48 & 15.25 & 13.94 & 19.39 \\
\hline Imanta & 20.81 & 20.23 & 19.22 & 20.36 \\
\hline 19922.29 & 19.6 & 20.31 & 18.26 & 20.56 \\
\hline 2008-6.5 & 20.9 & 21.00 & 19.18 & 15.86 \\
\hline Magdalena & 21.17 & 21.11 & 19.41 & 19.89 \\
\hline Gogla & 17.09 & 15.23 & 15.27 & 19.23 \\
\hline Kundega & 19.6 & 20.86 & 19.22 & 19.91 \\
\hline
\end{tabular}

The highest starch content was found in 2019 for the variety 'Kuras' (21.32\%) and for clones $19922.29(21.0 \%)$ and 2008-6.5 (21.11\%), also the following year these clones had a high starch content of $(20.9 \%)$ and $(21.17 \%)$, respectively. The high starch content in 2020 was also for the early varieties 'Monta' and 'Rigonda', 'Prelma' (21.17 \%), which can be explained by the warm and sunny August and plant foliage was not infected by late blight ( Phytophtotora infestans), resulting in more starch accumulating in the tubers. In 2018, many varieties and clones had a significantly lower starch content compared to 2019 and 2020 ( $\mathrm{p}<0.05$ ). Studies elsewhere have also shown that starch content depends on several factors: genotype, growing and climatic conditions. In Poland, in the studies of A. Kitas, the starch content of five varieties ranged from 14.98 to $18.4 \%$ (Kita, 2002), while in Italy the starch content of same varieties ranged from 12.22 to $18.63 \%$ (Finotti et al., 2006).

The starch yield of potato varieties and clones is closely correlated with several factors: the starch content of the genotype, the tuber yield and the weather conditions. The correlation coefficient on average over 3 years was $r=0.76033$, it indicated that there was a positive linear relationship between tuber yield and starch yield: with increasing tuber yield, starch yield increased, but the coefficient $r=0.38864$ indicated that there is a positive linear relationship between starch content and starch yield: with increasing starch content, starch yield increased. Studies elsewhere also showed a strong positive correlation between precipitation and potato productivity $(\mathrm{r}=0.661)$ (Norten and Gurung, 2020).

Table 2. Starch yield of potato genotypes, $\mathrm{t} \mathrm{ha}^{-1}$

\begin{tabular}{|l|l|l|l|c|}
\hline Varieties/ breeding materials & 2018 & 2019 & 2020 & ${\text { Average, } \mathrm{t}^{-1}}^{-1}$ \\
\hline Monta & 2.33 & 2.84 & 3.14 & 3.77 \\
\hline Rigonda & 3.25 & 2.99 & 3.51 & 3.22 \\
\hline S 07169-35 & 3.13 & 3.67 & 3.86 & 3.03 \\
\hline 2001-33.17 & 2.57 & 3.25 & 2.40 & 2.80 \\
\hline Lenora & 2.52 & 3.12 & 2.89 \\
\hline Prelma & 3.09 & 3.49 & 4.51 & 3.19 \\
\hline S 07131-15 & 4.25 & 2.46 & 3.56 & 2.92 \\
\hline S 10063-128 & 4.42 & 3.82 & 3.06 & 4.18 \\
\hline S 10063-48 & 3.31 & 3.79 & 3.56 & 3.68 \\
\hline S 09035-22 & 4.78 & 2.56 & 4.04 & 3.26 \\
\hline 19694.5 & 4.21 & 4.21 & 2.92 & 4.59 \\
\hline S 07156-22 & 2.43 & 2.80 & 3.94 & 4.14 \\
\hline Brasla & 5.12 & 4.43 & 3.59 & \\
\hline Imanta & 4.68 & 4.69 & & \\
\hline
\end{tabular}




\begin{tabular}{|c|c|c|c|c|}
\hline 19922.29 & 5.74 & 6.46 & 3.93 & 5.38 \\
\hline $2008-6.5$ & 6.35 & 5.59 & 4.17 & 5.37 \\
\hline Magdalena & 3.90 & 2.50 & 3.26 & 3.22 \\
\hline Jogla & 4.75 & 7.07 & 4.80 & 5.54 \\
\hline Gundega & 3.77 & 3.33 & 3.65 & 3.58 \\
\hline Kuras & 5.17 & 7.48 & 5.90 & 6.18 \\
\hline RS ${ }_{0.05=1.13}$ & & & & \\
\hline
\end{tabular}

Starch yield for potato varieties and clones differed significantly between growing years. The highest starch yield was for cultivars 'Kuras' - 7,48 $\mathrm{t} \mathrm{ha}^{-1}$ and 'Jogla' - $7.1 \mathrm{t}$ ha ${ }^{-1}$ in 2019, and for clones 19922-29 - $6.5 \mathrm{t} \mathrm{ha}{ }^{-1}$ and 2008-6.5 - 5.6 $\mathrm{t} \mathrm{ha}^{-1}$, which can be explained by higher tuber yields for these varieties and clones and high starch content - above $20 \%$.

\section{CONCLUSIONS}

- The highest starch content was found in 2019 for the variety 'Kuras' (21.32\%) and for clones 19922.29 (21.0 $\%)$ and 2008-6.5 (21.11\%);

- the highest starch yields were obtained in 2019 for potato variety 'Kuras' $-7.5 \mathrm{t}$ ha, 'Jogla' $-7.1 \mathrm{t} \mathrm{ha}{ }^{-1}$ and for clones 19922-29-6.5 $\mathrm{t} \mathrm{ha}^{-1} ; 2008-6.5-5.6 \mathrm{t} \mathrm{ha}^{-1}$;

- In 2018, many varieties and clones had a significantly lower starch content compared to 2019 and 2020 (p<0.05).

Acknowledgments. The research was executed in frame of Crop Breeding Programme, supported by Ministry of Agriculture, the research presentation was funded by the Latvian Counsil of Science, project "Potato breeding for low input and organic farming systems: nitrogen use efficiency and quality aspects of potato protein", No. lzp-2019/1-0371.

\section{REFERENCES}

1. Finotti E., Bertone A., Vivanti V. 2006. Balance between nutrients and antinutrients in nine Italian potato cultivars. Food Chemistry, No. 99(4), p.698 - 701. https://doi.org/10.1016/j.foodchem.2005.08.046

2. Hajšlova J., Shulzova V., Slanina P., Janne K., Helenas K.E., Andersson C.H. 2005. Quality of organically and conventionally grown potatoes : fore-year study of micronutrients, metals, secondary metabolites, enzymaticbrowning and organoleptic properties. Food Additives and Contaminants, Vol. 22, pp. 514-534. https://doi:10.1080/02652030500137827

3. Herencia J.F., Garcia-Galavis P.A., Ruiz Dorado J.A., Maqueda C.A. 2011. Comparison of nutritional quality of the crops grown in an organic andconvetional fertilized soil. Scientia Horticulturae, Vol. 129, pp. $882-888$. https://doi.org/10.1016/i.scienta.2011.04.008

4. Jimenez M.E., Rossi A.M., Samman N.C. 2009. Phenotypic, agronomic, nutritional characteristics of seven varieties of Andean potatoes. Journal of Food Composition and Analysis, No.22, pp. 613 - 616. https://doi.org/10.1016/j.jfca.2008.08.004

5. Kita A. 2002. The influence of potato Chemical composition on crisp texture. Food Chemistry, No.79, pp.173 - 179. https://doi.org/10.1016/S0308-8146(01)00260-6

6. Kuur L., Singh Sodshi N., Singh Gujral H. 2002. Soome properties of potatoes and their starches.I. Cooking, texture and rheological properties of potatoes. Food Chemistry, No.79, p.177 - 181. https://doi.org/10.1016/S0308-8146(02)00129-2

7. Li X., Scanlon M.G., Liu Q., Coleman W.K. 2006. Processing and value addition. In: Potato Production Improvement and Post harvest Management . J. Gopal \& A. M. P. Khurana (Eds). New York: Haworh Press, p. 523 - 555.

8. Norten U., Gurung T. 2020. Impact of climate variability on potato production in chang Gewog ThiphuDzonghag. Agriculture \& Food Security, Vol. 7(79), pp. 1-13. https://doi.org/10.1186/s40066-018-0229-6

9. Skrabule I., Mežaka I., Venta N., Vojevoda L. 2018. Cietes ražošanai piemērotā kartupeḷu šḳirne "Jogla". Proceeding of the Scientific and Practical Conference 'Harmonious Agriculture'. LLU, Jelgava, Latvija, pp. 91-95.

10. Soest J.J.G. 1996. Starch and starch plastics. In: Starch plastics: structure - properties relationships. Dan Haag: CIP-Gegevens Koninnklijke bibliotek, p. $9-33$.

11. Stijn R., Ooms H., Gomond S.V., Delcour J. A. 2020. What makes starch from potato (Solanum tuberosum L.) tubers unique: A review. Comprehensive Reviews in Food Science and Food Safety, pp. 2588-2612. https://doi.org/10.1111/1541-4337.12596

12. Симаков Е.А. Перспективы селекции сортов картофеля для диетического питания/Е.А. Симаков, И.М.Яшина/Картофелеводство:сборник научных трудов/НПЦ НАН Беларуси по картофелеводству и плодоовощеводству. - Минск, 2008. - Вып.14. - С.296 -303. 